ScienceDirect

BIOETHICS UPdate 6 (2020) 67-79
BIOETHICS UPdate

UNIVERSIDAD PANAMERICANA

Original article

\title{
The pandemic and the ethical dilemma of limited resources: Who to treat?
}

\author{
La pandemia y el dilema ético de los recursos limitados: \\ ¿a quién tratar?
}

Laura Palazzani

Libera Università Maria Ss.ma Assunta (LUMSA), Rome, Italy

Received 27 August 2020; accepted 3 September 2020

Available online 24 September 2020

\begin{abstract}
The different ethical perspectives on the issue of distribution of scarce resources are discussed in this article. While the problem of distribution of resources does not exist in an ideal situation with sufficient availability of resources for everyone, in fact, in the context of a pandemic the distribution of scarce resources is revealed in a dramatic and urgent way. As regards this issue, there is agreement on the fact that distribution should be "fair", according to the shared meaning of justice as "not to harm others" and to "give each his own". However, within the pluralist discussion, there are different ways of conceiving justice on a theoretical level and applying it at a concrete level. This article examines classical bioethical theories that are reappearing in the discussion today - with different levels of intensity, or in different formulations - and this, in the
\end{abstract}

E-mail address: palazzani@lumsa.it 
light of the most important international and national ethical guidelines and recommendations on the distribution of resources during the COVID-19 pandemic.

(C) 2020 Centros Culturales de México, A.C. Published by Masson Doyma México S.A. All rights reserved.

Keywords: COVID-19; Pandemic; Distribution of resources; Justice; Ethics

\section{Resumen}

El artículo discute diferentes perspectivas éticas sobre el tema de la distribución de recursos escasos. Si bien en una situación ideal con suficiente disponibilidad de recursos para todos no existe el problema de distribución de recursos, de hecho en el contexto de una pandemia la distribución de recursos escasos se revela de manera dramática y urgente. Sobre este tema, hay acuerdo en que la distribución debe ser "justa", según el significado compartido de la justicia como "no dañar a los demás" y "dar a cada uno lo suyo". Sin embargo, dentro de la discusión pluralista existen diferentes formas de concebir la justicia a nivel teórico y aplicarla a nivel concreto. El artículo examina las teorías bioéticas clásicas que están reapareciendo en la discusión hoy - en diferentes niveles de intensidad, o en diferentes formulaciones - y esto a la luz de las más importantes directrices y recomendaciones éticas internacionales y nacionales sobre la distribución de recursos durante el COVID-19 pandemia.

(C) 2020 Centros Culturales de México, A.C. Publicado por Masson Doyma México S.A. Todos los derechos reservados.

Palabras clave: COVID-19; Pandemia; Distribución de recursos; Justicia; Ética

\section{Introduction}

The issue of the distribution of health resources is certainly not a new topic in bioethics. For some time, medical ethics has raised the problem at different levels and in different areas.

The problem lies in the 'macro-distribution' of resources, that is, the decisions taken in the context of health policies in the broad sense (how much to invest in health and in which sectors as a priority, compared to other investments). These decisions are shaped differently in the various countries of the world, in the different political, economic and social contexts. It is also a problem of 'micro-distribution', that is, of decisions that healthcare facilities and doctors have to make when resources are 
limited in relation to the amount of patients' requests. Hence the emergence of a problem at the centre of bioethical debate of how to allocate scarce resources (see also the Italian Committee for Bioethics, 1998 and Italian Committee for Bioethics, 2001). In an ideal situation with sufficient availability of resources for everyone, the problem does not exist: but reality shows us, inexorably, the inevitability of the problem. Think of medicine in scenarios of war and disaster medicine; access for those waiting for organ transplants; the definition of priorities in the 'daily' management of emergency departments, hospitalizations, the use of expensive drugs or technologies.

The COVID-19 pandemic makes the existence of the problem evident in a dramatic and urgent way. On the one hand the rapid and exponential growth of the infection (the high percentage of patients requiring hospitalizations, access and even prolonged stay in intensive care units with the use of assisted ventilation), and on the other the limit of the resources (number of beds, availability of drugs and technologies, the presence of medical and nursing staff), expose the alarming and dramatic possibility of such choices. All possible efforts are being made to expand distributable resources to avoid being faced with the tragic decision of who to treat and who not to treat: by increasing the number of beds in intensive care, transforming and setting up new wards, transferring patients to other facilities, buying necessary technologies, increasing staff, providing new facilities, urging citizens to be responsible in their behaviour to avoid getting sick and transmitting the infection.

But if and when one is faced with the choice of who to include and who to exclude from hospitalization, from access to intensive care or ventilation, is it possible to choose? And, on what basis does one choose? These are the main questions which arise. The 'random lottery' or draw as a criterion for solving the distribution dilemma is unacceptable: even if, at times, given the impossibility of making a decision, it would seem to be the only possible solution ${ }^{1}$. The problem of allocating resources in healthcare is bound to remain unavoidably open: the task of bioethics in this regard is not to solve it, but only to indicate and justify the ethical criteria of reference on an inevitably abstract level with respect to the concreteness of the dramatic situation of those who are in the front line. There is agreement on the fact that distribution should be "fair", according to the shared meaning of justice as "not to harm others" and

\footnotetext{
${ }^{1}$ The story "The lottery in Babylonb̈y J.L. Borges speaks of a society in which benefits and burdens are distributed by a periodic lottery: the extravagance of the story comes from the fact that random selection does not take into account actions, merit, skills, needs or anything else. But only if it appears unfair. Only in some cases of unsolvable dilemmas, where there is no justification whatever the rational choice, can the fate and lottery criterion appear to be the only 'right' one (see Dickenson, 1995).
} 
to "give each his own". But, within the pluralist discussion there are different ways of conceiving justice on a theoretical level and applying it on a concrete level. And these theories are reappearing in the discussion today, in different levels of intensity, or in different formulations.

\section{Different ethical approaches}

The theory of libertarianism, starting from an individualistic anthropology (see Charlesworth, 1993; Engelhardt, 1996), interprets justice as the protection of self-determination: "not to harm" others assumes the meaning of not preventing, hindering or restricting the freedom of others; "Giving each his own" takes on the meaning of attributing resources to each individual according to his will, merits, abilities, the contribution he provides, free initiative. In this perspective, inequalities are inevitable, and are considered the result of "bad luck", but not of "injustice". Society is not obliged to repair damages, since there is no "direct obligation" to help the needy, as the needs of others should not condition individual freedom.

In this perspective, the individual has no legal entitlement to treatment and health care in the free market of private assistance: the rights of autonomy of individuals prevail over social obligations of beneficence. In the choice regarding patient selection, the young tend to be prioritised over the elderly, the rich over the poor, individuals who hold important social positions over the unemployed, those who are more autonomous over those who are less or no longer so. It is an economistic approach, according to which the selection of patients for treatment is based on individual free choice and the ability to pay.

Still present on the level of theoretical debate, this theory is not sparsely mentioned in the context of discussion on the COVID-19 pandemic, and even the health systems of the countries inspired by this model have sought and are still seeking solutions to protect public health, due to the inevitable inequalities that it entails on the socio-economic level. In some respects, the political proposal based on 'herd immunity' follows this approach, which tends to favour exposure to the risks of the most vulnerable people with the aim of immunising the community (thanks to them they themselves are saved from the disease), with overall benefits and lower economic costs. It is a criticized economist approach on the scientific level since it is neither proven nor shared by scientists, with possible (foreseeable) negative consequences for individuals at national and international level, and with an inevitable increase in inequalities. 
The German Ethics Council, in the opinion Solidarity and Responsibility during the Coronavirus Crisis, Ad Hoc Recommendation (The German Ethics Council, 2020), explicitly addresses the issue by distancing itself from the libertarian model, in the specific context of Covid-19: "Given the characteristics of the new virus, the distribution of risks, and the expectations of the impact on the health system, particularly on the hospital system, the laissez-faire strategy seems irresponsible". The UNESCO International Bioethics Committee (IBC) also expressed its opinion in this direction, which together with the World Commission for the Ethics of Scientific Knowledge and Technologies (COMEST) with the document Statement on Covid-19: Ethical Considerations from a Global Perspective (UNESCO International Bioethics Committee (IBC) \& the World Commission for the Ethics of Scientific Knowledge \& Technologies (COMEST), 2020), which affirmed a position against the notion of 'herd immunity', believing that it "needs a cautious ethical review, considering the impact on the number of lives exposed to threats and unsustainable medical conditions given the lack of availability of intensive care facilities even in developed countries: In a context of uncertainty with possible devastating negative consequences for the health and life of individuals and communities, it makes policies based on this notion "unethical practices" because they act in an individualistic direction, against the effort to build a common global response to the pandemic.

The libertarian model is therefore the object of criticism for the human and social implications that it brings, in particular towards the weakest, the poor and the marginalized. This model does not adequately take into account the social effects of individual actions, in the false hope that an "invisible hand" will solve problems, accentuating subjective egoism, the cold logic of calculation and indifference to needs, denying the constitutive dimension of social responsibility towards oneself and towards others.

A theory at the centre of the bioethical discussion in relation to the COVID-19 pandemic is the utilitarian view (see Singer, 1993; Harris, 1985). This view, based on the cost/benefit calculation to obtain the greatest benefit for the largest number of people, believes that the selective choices are justified when they achieve the greatest collective result expressed by the formula "quality adjusted life years" (QALY), i.e. the number of years of life taking into account the quality and costs, for the greatest number of individuals. The allocation of limited resources in terms of access to care is deemed to be correct when it achieves, at the same expense, the best possible pragmatic result in relation to convenience and efficiency, therefore combining the 
number of patients who survive, the years of life left to live, with quality. In the selective choice of the patient for treatment and care, it favours those most likely to return to a life projected into the future with a good quality of life at a low cost.

In this perspective, the right to access treatment and health care is recognised only to those who have a life "worthy" of being lived in relation to the achievement or likelihood of achieving an expected number of years of life left to live and a certain standard of quality of life ${ }^{2}$. It is however a weak right, subject to the maximization of overall profit and may not allow for access to health care for the weaker social groups of our society, with the consequent marginalisation of the elderly, the disabled, the poor. It is in this context that the debate on so-called "ageism", that is, discrimination based on age: the utilitarian approach is an approach that inevitably, explicitly or implicitly, correlates the maximum benefit obtainable with the prioritisation of younger people over older people, who have less life expectancy (in terms of the number of years left to live as well as the presumed level of quality of life) and, moreover, they have already lived years of life.

The utilitarian orientation is present, albeit with mitigated tones, in the document of the World Health Organization, before Covid-19, with general reference to the pandemics Guidance for Managing Ethical Issues in Infectious Disease Outbreaks (World Health Organization (WHO), 2016), where reference is made to "Total number of lives saved, total number of life years saved, or total number of 'quality-adjusted life years saved'", even if balanced with reference to equity and the duty not to abandon vulnerable patients. Along this line, the Sociedad Española de Medicina Intensiva Crítica y Unidades Coronarias and the Sociedad Española de Enfermería Intensiva y Unidades Coronarias, Plan de Contingencia para los Servicios de Medicina Intensiva frente a la pandemic COVID-19 (Sociedad Española de Medicina Intensiva Crítica y Unidades Coronarias (SEMICYUC) \& Sociedad Española de Enfermería Intensiva y Unidades Coronarias (SEEIUC), 2020), with explicit reference to limit of treatments for elderly people (including age) and people with cognitive disabilities. This discussion emerged in Italy with reference to the document to the Italian Society of Anesthesia Analgesia Resuscitation and Intensive Therapy (SIAARTI), Recommendations of clinical ethics for admission to intensive treatments and for their suspension, in exceptional conditions of imbalance (Società Italiana di Anestesia, Analgesia, Rianimazione e Terapia Intensiva (SIAARTI), 2020). In the dramatic situation of the Covid-19 pandemic, this approach

\footnotetext{
2 This approach, balanced with a call to equity, also in WHO, 2016: "total number of lives saved, the total number of life years saved, or the total number of quality-adjusted life years saved".
} 
expresses some criteria for health professionals who are forced to make selective choices, with the aim of relieving them of the burden of responsibility of these decisions. The first point expressed in the document is that there is "not necessarily a need to follow a criterion for access to intensive care, such as "first come, first served": in other words, this approach seems to admit the possibility of not allowing a 'present' patient access, leaving open the possibility of treating a later arriving 'future' patient who may have a better prognosis. The second issue concerns the possibility of "placing an age limit on entry into intensive care", firstly in order to allow access "to those who have the most chance of survival and secondly to those who can have more years of life saved, with a view to maximizing the benefits for the greatest number of people". It should be acknowledged that the principle of the "probability of survival" remains primary, however the anagraphic data is also introduced (number of years of life saved) on equal terms. In another part the document states "the presence of comorbidities and functional status should be carefully evaluated, in addition to age", this would seem to make age a primary criterion to which the clinical and prognostic criteria are added. The reason that justifies this choice in the document is explained with reference to the fact that the same resources could be used for a shorter time for a patient in less serious conditions, saving money compared to their being used for elderly and frail patients. While recognising the exceptionality of the current dramatic situation, this approach risks introducing utilitarian criteria into 'normal' practice.

The criteria of the utilitarian vision are susceptible to a fundamental objection: these are criteria that deny the authentic meaning of justice, which recognises the dignity of every human being recognised as person without making extrinsic distinctions between lives with dignity or without dignity, lives with greater dignity or lesser dignity, based on conditions regarding quality of life, number of years left to live, or productivity. The utilitarian criteria, similar to those of the libertarian vision (albeit based on different theory and arguments) are in contrast with fundamental human rights, including the right to the protection of health, expressed in international constitutions and regulations, as well as in deontological codes ${ }^{3}$. These criteria are not compatible with the fundamental right to health. Moreover, the QALY criterion is susceptible to further scientific and philosophical objections: the uncertainty and difficulty in calculating the probabilistic prediction of the number of years of life left to live; the subjectivity of the way of understanding and living the quality of life (not projectable on others); the individual variability compared to

\footnotetext{
${ }^{3}$ For a critique of libertarian and utilitarian models see Petrini (2010).
} 
the generalized 'average' referring to groups of individuals (for example, using age as a selection criterion, does not consider the individual physiological variability of individual persons, regardless of age).

Given the limitations of libertarian and utilitarian theories, which theoretical model is most in line with the fundamental right to individual health?

One path is outlined by the theory that echoes the egalitarianism of J. Rawls (see Rawls, 1971; Daniels, 1981) in the fictitious hypothesis of an "original position" behind a "veil of ignorance", that is, if each of us ignored who he/she is (our own age, personal and social condition) we could not but accept the criterion of justice in distribution as a "fairer" criterion, the one based on clinical urgency or a random draw. The draw is susceptible to criticism, as there is the risk of wasting resources which, being scarce, must be used, at least presumably, effectively. But the egalitarian theory is based on the recognition for all individuals to have equal or equitable access opportunities.

The theorisation of equality and equal access is also supported by other theories, with different arguments. T.L. Beauchamp and J.F. Childress, based on the theorisation of "principlism", believe that there is a right to a "decent minimum of care" and that health care is an aspect of social protection against external threats from which the individual alone cannot protect himself, as in the case of the pandemic (see Beauchamp \& Childress, 2012; Childress, 1981). This position is also shared by the personalist theory that recognises the ontological primacy of the dignity of the human person (see Pellegrino \& Thomasma, 1987), from the community theory (see Emanuel, 2000) that justifies the duty of solidarity, as an obligation to take care of citizens and especially the most vulnerable and the theory of virtue (see Pellegrino, E.D., 2002), which gives a centre role to the deontological responsibility of the doctor towards those who are most in need.

If we examine the problem of the selection of patients for access to care in search of the ethical criterion compatible with respect for dignity and justice, the only criterion is objective medical assessment, case by case, of the clinical condition, urgency, the severity, the possible presence of other diseases and the presumed prognostic efficacy of the treatment in terms of probable recovery, according to the criteria 
of proportionality and appropriateness ${ }^{4}$. Any deviation from this logic introduces arbitrary elements of discrimination.

The criterion of age or prioritising of a life less-lived and more open to the future over a life already lived, a possible quality of life, financial means, social role, dependency, production efficiency or capacity, social cost, responsibility in acquiring the disease, nationality, ethnicity, are criteria which, if applied, arbitrarily establish inequalities between human beings.

This is the position expressed by the Comité Consultative National d'Etique in the document Enjeux éthiques face à une pandémie (Comité Consultative National d'Etique por le Sciences de la Vie et de la Santé, 2020) ${ }^{5}$. The Nuffield Council on Bioethics in the document on Ethical considerations in responding to the COVID-19 pandemic (Nuffield Council on Bioethics, 2020), while focusing mainly on social policy issues, reiterates the need for an 'impartial' criterion for micro-distribution that recognises an "equal moral worth to all. Similar position the Committee for Bioethics of Spain Informe sobre los aspectos bioéticos de la priorizaciòn de recursos sanitarios en él contexto de la crisis del coronavirus (Spanish Bioethics Committee, 2020), the Austrian Commission Zum Umgang mit knappen Ressourcen in der Gesundheits Versorgung im Kontext der Covid-19-Pandemie (Austrian Bioethics Commission, 2020) and the Conselho Nacional de Ética para as Ciências da Vida in Portugal with the document The Public Health Emergency caused by the Covid-19 Pandemics, Relevant Ethical Issues (Conselho Nacional de Ética para as Ciências da Vida, 2020), the Committee in Luxembourg Repères éthiques essentiels lors de l'orientation des patients dans un contexte de limitation des ressources thérapeutiques disponibles due à la crise pandémique du COVID-19 (Commission Consultative Nationale d'Ethique pour les sciences de la Vie et de la Santé (C.N.E.) - Grand-Duché de Luxembourg (2020)).

Also some societies of intensivists expressed their position in this direction. A path has been traced in the document by the Belgian Society of Intensive care medicine Ethical principles concerning proportionality of critical care during the 2020 COVID-19 pandemic in Belgium: advice (Belgian Society of Intensive care medicine, 2020), which states: "Although advanced age is associated with worse

\footnotetext{
${ }^{4}$ As in general in clinical practice, disproportion or unreasonable obstinacy in treatment (to be considered ineffective, futile and burdensome) is not ethically justifiable.

${ }^{5}$ The document incorporates principles outlined in the previous document Questions éthiques soulevées par une possible pandémie grippale, 2009.
} 
outcomes in COVID-19, age in isolation cannot be used for triage decisions, but should be integrated with other parameters"; "Many COVID-19 patients are elderly, but age itself is not a good criterion for deciding on the disproportionality of care. Priorities should be decided on the basis of medical urgency. In the event of a comparable medical emergency, the "first come first served" principle, and the criterion of "random" selection are the most useful and equitable". This is the egalitarian approach which, on the basis of the equality of all human beings, opts in the case of limited access to resources for the principle of first come first served and in the event of the simultaneous arrival of patients in the draw, therefore in randomness deemed the "fairest" in any possible choice that could be discriminatory. Also along these lines is the document The Ethical Framework for Health Care Institutions Responding to Novel Coronavirus SARS-CoV-2 (COVID-19) Guidelines for Institutional Ethics Services Responding to COVID-19 Managing Uncertainty, Safeguarding Communities, Guiding Practice of the Hastings Center (Hastings Center, 2020), which recalls the relevance of clinical ethics committees in support of complex decisions, and recalls the principle of equality and equity in the allocation of scarce resources.

The National Committee for Bioethics in Italy in the Covid-19 opinion The Clinical Decision in Conditions of Lack of Resources and the Criterion of "Triage in Pandemic Emergency (Italian Committee for Bioethics, 2020) starting from the human rights framework and the Constitutional principles, reaffirms that "it is always necessary to do everything possible to guarantee everyone, without exception respecting "the principles of justice, fairness and solidarity, to offer all people equal opportunities to reach the maximum health potential allowed".

On this position, on an international level, the Committee for Bioethics (DHBIO) of the Council of Europe Statement in the Context of the Covid-19 Crisis (Committee for Bioethics of the Council of Europe (DH-BIO), 2020), which recalling The Convention of Human Rights and Biomedicine (Council of Europe, 1997) affirms the principle of equity of access to care without any discrimination. The European Group on Ethics in Science and New Technologies at the European Commission in the Statement on European Solidarity and the Protection of Fundamental Rights in the Covid-19 Pandemic (EGE, 2020), affirms the principles of dignity, justice, solidarity, as the basis of a common European ethics. The International Committee for Bioethics and the World Commission on the Ethics of Scientific Knowledge and Technology Statement on Covid-19: Ethical Considerations from a Global Perspective (UNESCO International Bioethics Committee (IBC) \& the World Commission for the Ethics of Scientific Knowledge \& Technologies (COMEST), 
2020), underlines the ethical foundation of macroallocation and microallocation on justice, beneficence and equity, putting medical need and effectiveness of treatment as prior consideration.

\section{Conclusion}

In this perspective, the equality of human beings as a fundamental value justifies allocation only on the basis of equity, that is, considering the concrete needs of the individual, in the circumstances. The starting point is the 'principle' recognition that everyone must be treated. If 'factual 'circumstances (such as the scarcity of resources) inevitably force us not to be able to treat everyone, but only to treat some and not others, the criterion cannot be defined on a subjective or social (non-medical) basis, rather it should be defined only on an objective (medical) basis, that is, on the basis of the patient's clinical condition. It is clear that scarce resources cannot be misused and wasted, they must be used effectively, that is, they must be used to save lives. However, we must not forget that the needs of every sick person must be placed at the centre.

In the case of the pandemic, it should also be remembered that this criterion should be applied to all patients: selection should not bring about differentiated treatment between infected patients and patients with other pathologies, as the monitoring of the continuity of care of other patients is an ethical duty. It is precisely those who are most vulnerable, such as the elderly, the disabled or the poor who should not be marginalized by selective logics inspired by individualism or social convenience.

However, this does not mean treatment 'at all costs' or the implementation of clinical obstinacy which must always be duly suspended when disproportionate, ineffective and burdensome, just as there must be respect for the patient's autonomy regarding the refusal or renunciation of treatments, when the patient is fully aware and informed of the consequences. Wherever the ventilation requirement (or the duration of ventilation) would prove to be ineffective or disproportionate.

Ethics is left with a task, that of justifying and recalling health care professionals to values in their actions, values that must be interpreted and applied in specific contexts, at the 'patient's bedside'. It is at this stage that doctors should be able to consult Clinical Ethics Committees, in order to facilitate discussion and provide support for their decisions, which are often complex to the point of being real 'dilemmas', so that whatever choice seems wrong. In some cases there is no time for such consultation or 
there are no such committees in the facilities themselves, and doctors are left alone in the decisions they have to make.

\author{
It is a dramatic situation which should be avoided: all ethical theories converge
} on this.

\title{
References
}

Austrian Bioethics Commission. https://www.bundeskanzleramt.gv.at/en/topics/bioethics-commission/ publications-bioethics.html, 2020

Beauchamp, T. L., \& Childress, J. F. (2012). Principles of biomedical ethics (7th ed.). Oxford: Oxford University Press.

Belgian Society of Intensive care medicine. https://www.zorgneticuro.be/sites/default/files/general/COVID-19ethical_final_c.cleaned.pdf, 2020

Charlesworth, M. (1993). Bioethics in a liberal society. Cambridge: Cambridge University Press.

Childress, J. F. (1981). Priorities in biomedical ethics. Philadelphia: Westminster Press.

Comité Consultative National d'Etique por le Sciences de la Vie et de la Santé. https://www.ccne-ethique.fr/sites/default/files/reponse_ccne_-_covid-19_def.pdf, 2020

Commission Consultative Nationale d'Ethique pour les sciences de la Vie et de la Santé (C.N.E.) - Grand-Duché de Luxembourg. https://cne.public.lu/dam-assets/fr/publications/avis/Prise-de-position-COVID-19.pdf, 2020

Committee for Bioethics of the Council of Europe (DH-BIO). https://rm.coe.int/inf-2020-2-statementcovid19-e/16809e2785, 2020

Conselho Nacional de Ética para as Ciências da Vida. https://www.who.int/ethics/topics/outbreaks-emergencies/ Pos-CNECV-Covid-19-EN.pdf?ua=1, 2020

Council of Europe. https://rm.coe.int/168007cf98, 1997

Daniels, N. (1981). Health care needs and distributive justice. Philosophy \& Public Affairs, 10, 146-179.

Dickenson, D. (1995). Is efficiency ethical? Resource issues in health care. In B. Almond (Ed.), Introducing applied ethics (pp. 229-246). Oxford: Blackwell.

Emanuel, E. J. (2000). Justice and managed care. Four principles for the just allocation of health care resources. The Hastings Center Report, 30(3), 8-16.

Engelhardt, H. T., Jr. (1996). Foundations of bioethics. New York: Oxford University Press.

European Group on Ethics in Science and New Technologies (EGE). https://ec.europa. eu/info/sites/info/files/research_and_innovation/ege/ec_rtd_ege-statement-covid-19.pdf, 2020

Harris, J. (1985). The value of life. London: Routledge.

Hastings Center. https://www.thehastingscenter.org/ethicalframeworkcovid19/, 2020

Italian Committee for Bioethics. http://bioetica.governo.it/en/opinions/opinions-responses/bioethical-guidelinesfor-equal-access-to-healthcare/, 2001

Italian Committee for Bioethics. http://bioetica.governo.it/media/4008/p136_2020_covid-19-clinical-decisionmaking-in-conditions-of-resource-shortage-and-the-pandemic-emergency-triage-criterion_en.pdf, 2020

Italian Committee for Bioethics. http://bioetica.governo.it/en/opinions/opinions-responses/ethics-health-care -system-and-resources/, 1998

Nuffield Council on Bioethics. https://www.nuffieldbioethics.org/assets/pdfs/Ethical-considerations-inresponding-to-the-COVID-19-pandemic.pdf, 2020

Pellegrino, E. D., \& Thomasma, D. C. (1987). A philosophical basis of medical practice. New York: Oxford University Press.

Petrini, C. (2010). Triage in public health emergencies: Ethical issues. Internal Emergencies Medicine, 5, $137-144$. 
Rawls, J. (1971). A theory of justice. Cambridge (Mass.): Belknap Press.

Singer, P. (1993). Practical ethics. Cambridge: Cambridge University Press.

Sociedad Española de Medicina Intensiva Crítica y Unidades Coronarias (SEMICYUC), \& Sociedad Española de Enfermería Intensiva y Unidades Coronarias (SEEIUC). https://www.semicyuc.org/covid19_files/Plan_de_Contingencia_COVID-19.pdf, 2020

Società Italiana di Anestesia, Analgesia, Rianimazione e Terapia Intensiva (SIAARTI). http://www.siaarti.it/SiteAssets/News/COVID19\%20-\%20documenti\%20SIAARTI/SIAARTI\%20-\%20 Covid19\%20-\%20Raccomandazioni\%20di\%20etica\%20clinica.pdf, 2020

Spanish Bioethics Committee. http://assets.comitedebioetica.es/files/documentacion/Informe\%20CBE$\% 20$ Priorizacion \%20de\%20recursos\%20sanitarios-coronavirus\%20CBE.pdf, 2020

The German Ethics Council. https://www.ethikrat.org/fileadmin/Publikationen/Ad-hoc-Empfehlungen/englisch/ recommendation-coronavirus-crisis.pdf, 2020

UNESCO International Bioethics Committee (IBC), \& the World Commission for the Ethics of Scientific Knowledge and Technologies (COMEST). https://www.unescobiochair.org/2020/03/31/ statement-on-covid-19-ethical-considerations-from-a-global-perspective-ibccomest/, 2020

World Health Organization (WHO). https://apps.who.int/iris/handle/10665/250580, 2016 